\title{
Opportunities and Challenges for the Sustainability of Lakes and Reservoirs in Relation to the Sustainable Development Goals (SDGs)
}

\author{
Long T. Ho *(D) and Peter L. M. Goethals \\ Department of Animal Sciences and Aquatic Ecology, Ghent University, 9000 Ghent, Belgium \\ * Correspondence: Long.tuanho@UGent.be; Tel.: +32-926-438-95
}

Received: 21 May 2019; Accepted: 6 July 2019; Published: 15 July 2019;

check for updates Corrected: 12 November 2021

\begin{abstract}
Emerging global threats, such as biological invasions, climate change, land use intensification, and water depletion, endanger the sustainable future of lakes and reservoirs. To deal with these threats, a multidimensional view on the protection and exploitation of lakes and reservoirs is needed. The holistic approach needs to contain not just the development of economy and society but also take into account the negative impacts of this growth on the environment, from that, the balance between the three dimensions can be sustained to reach a sustainable future. As such, this paper provides a comprehensive review on future opportunities and challenges for the sustainable development of lakes and reservoirs via a critical analysis on their contribution to individual and subsets of the Sustainable Development Goals (SDGs). Currently, lakes and reservoirs are key freshwater resources. They play crucial roles in human societies for drinking water provision, food production (via fisheries, aquaculture, and the irrigation of agricultural lands), recreation, energy provision (via hydropower dams), wastewater treatment, and flood and drought control. Because of the (mostly) recent intensive exploitations, many lakes and reservoirs are severely deteriorated. In recent years, physical (habitat) degradation has become very important while eutrophication remains the main issue for many lakes and ponds worldwide. Besides constant threats from anthropogenic activities, such as urbanization, industry, aquaculture, and watercourse alterations, climate change and emerging contaminants, such as microplastics and antimicrobial resistance, can generate a global problem for the sustainability of lakes and reservoirs. In relation to the SDGs, the actions for achieving the sustainability of lakes and reservoirs have positive links with the SDGs related to environmental dimensions (Goals 6, 13, 14, and 15) as they are mutually reinforcing each other. On the other hand, these actions have direct potential conflicts with the SDGs related to social and economic dimensions (Goals 1, 2, 3 and 8). From these interlinkages, we propose 22 indicators that can be used by decision makers for monitoring and assessing the sustainable development of lakes and reservoirs.
\end{abstract}

Keywords: Lake; reservoir; sustainability; management; ecosystem service; threat; opportunity; SDGs; interlinkages

\section{Introduction}

Despite being a small component of the biosphere, most inland lakes and reservoirs are exploited for diverse human activities [1]. They provide a wide range of ecosystem services, including flood control, biodiversity, climate change mitigation, river flow regulation, hydropower supply, as well as water purification and storage [2]. In recent decades, emerging global threats, such as biological invasions, climate change, land use intensification, and water depletion, have been driving forces of changes in lakes and reservoirs. Particularly, these freshwater bodies are considered among the most 
impacted by species invasion, as invasions appear to be a principal contributor to biodiversity loss in numerous systems [3]. Cumulative invasions have disproportionately transformed the communities living in lakes and reservoirs in a way that non-native species have dominated more than their terrestrial counterparts do. For example, Ricciardi et al. [4] found that zebra mussel invasion has increased the impacts of environmental stressors, causing a 10-fold increase in local extinction rates of native mussels in the Great Lakes. Another example is the introduction of different types of fish to lake habitats for aquaculture and recreational fishing. In the beginning, fish introduction was evaluated with assumptions that the new species would integrate into new communities with no consequences [5]. However, this was not the case as the beneficial effects of the fish introduction were proved only immediate while negative impacts could threaten the perseverance of native communities [6].

Lakes and reservoirs are closely linked to climate change and mitigation. On the one hand, new findings indicate their significant roles in climate change mitigation as a major organic carbon sink in global biogeochemical cycles [7-10]. Moreover, with their large capacity of water storage, lakes and reservoirs have served as hydrological buffers preventing extreme climate events, such as floods, or snow and glacier melt, which are highly likely to occur more frequently as a result of climate change [2]. On the other hand, climate change is a major threat to the sustainable development of lakes and reservoirs [11]. According to IPCC [12], the shifts in climate regimes and their associated changes in global precipitation, evapotranspiration, and runoff patterns have caused alterations in flow and thermal regimes with more severe and inevitable drought and flooding events. Increasing temperature has had a significant impact on top predators, such as pike (Esox lucius), causing alterations in the topological architecture of food webs and whole ecosystem sensitivity to climate variation [13].

Other major threats, closely linked to anthropogenic pressures, are land-use intensification, nutrient enrichment, hydrological modification, aquaculture, and fisheries. These pressures have caused habitat loss and degradation, eutrophication and pollution, food web alteration, and physical degradation, in many inland water bodies. It was estimated that the human footprint has significantly influenced more than $83 \%$ of the land surface surrounding freshwater systems [14]. More importantly, as a result of the implementation to achieve the Sustainable Development Goals (SDGs) focusing on economic and social dimensions, such as the SDGs related to food, health, land, and climate, more pressure on the freshwater resources is likely to occur [15]. To avoid further degradation and promote the restoration and protection in lake and reservoir ecosystems, a more holistic and integrated approach is needed to deal with the potential pressures. As such, this study meticulously investigates the interlinkages between the necessary implementation for achieving a better and more sustainable future of lakes and reservoirs and the actions in the framework of the Sustainable Development Goals (SDGs). More specifically, in the first part, an overview of the development of lakes and reservoirs is provided with the focus on their status, ecosystem services, and current management and policy. This overview is derived from a multi-disciplinary review of the literature in order to provide a comprehensive overview of the development of lakes and reservoirs. In the second part, the main challenges and opportunities of the sustainability of lakes and reservoirs are depicted. To illustrate the whole picture of publications related to the sustainable development of lakes and reservoirs, a bibliographic analysis on approximately 65,000 publications related to lakes and reservoirs from 2009 to 2018 is implemented. Lastly, a critical review on the interlinkages between the necessary implementation for the sustainable development of lakes and reservoirs and the SDG is presented. As a result, we propose a list of 22 indicators, which can be used for monitoring the sustainable development of lakes and reservoirs.

\section{Overview of Lake Development: Status, Ecosystem Services, and Management}

\subsection{Status}

Natural lakes and artificial reservoirs cover only approximately five million $\mathrm{km}^{2}$ of the earth's surface; hence, $3.7 \%$ of the Earth's non-glaciated land surface has long been considered as a minor component of the biosphere [16]. However, due to extensive human exploitation, their status has been 
significantly deteriorated. According to the Living Planet Index 2018, 83\% of freshwater species have disappeared since 1970. Particularly, freshwater fish extinction rates have become extremely high [17]. Hence, we urgently need effective policy solutions that can achieve both water security and biodiversity. Moreover, recent studies proved the crucial roles of lakes in global biogeochemical cycles as well as the sustainability of human society as a main source of freshwater for human consumption [18]. A recent lake inventory by Verpoorter, Kutser, Seekell and Tranvik [16] showed that there are approximately 117 million lakes and reservoirs on Earth, larger than $0.002 \mathrm{~km}^{2}$. These lakes and reservoirs serve as a water resource for irrigation, industrial applications, fisheries, and hydroelectricity generation. A rapid increase in the number of hydropower reservoirs has gone up to 50,000 large dams which can store up to $8300 \mathrm{~km}^{3}$, approximately $10 \%$ of total natural water lakes on Earth [19,20]. Apart from these supporting, provisioning, and regulating services, lakes, and reservoirs also provide high values of cultural ecosystem services, i.e., recreational, cultural, educational services. Although the related values of these services are high, there remain substantial debates on the calculation of their economic values due to the diversity of service categories, types and valuation methods [21], and therefore tools and methods to quantify the social economic values need more research, standardization, and recognition by stakeholders and policy makers [22].

Because of increasing anthropogenic uses from these freshwater bodies, impacts on lakes and reservoirs are increasingly reported. Regarding physical degradation, the rapid increase of hydropower reservoirs and other anthropogenic interventions generate severe impacts on the hydromorphology, flow discharge, and inter-basin transfers, which, consequently, exacerbates ecological states with the habitat and species of connected water bodies [23]. Especially noteworthy is hydropeaking, a common phenomenon in hydropower reservoirs, during which the base flow is periodically disrupted by extreme and short-duration fluctuations, occurs more frequently due to the peak demand for electricity during the day [24]. These peak-events generate a fluctuating daily pattern of water flows that typically severely impairs productive, downstream shoreline habitats through repeated wetting and drying [25]. The most obvious form of habitat loss is the direct physical destruction of the habitats themselves upstream or downstream or in the surrounding area, and the loss of connectivity between them. The disruption of natural hydromorphological processes can moreover alter biotic and abiotic conditions that are vital for the natural ecosystem functioning, in some cases leading to the emergence of invasive species and evolution towards very different ecosystem components and processes [26]. In some of these cases, vectors responsible for the transfer of diseases can become more abundant due to a lack of predators [27].

Moreover, due to industrialization and intensive agriculture, eutrophication and heavy metals have become one of the most serious problems facing lakes and reservoirs. Eutrophication has caused turbid and toxic water from algal and cyanobacterial blooms, leading to the degradation of lake ecosystems and biodiversity in approximately $40 \%$ of the total number of lakes worldwide [28]. This contamination has been increasingly observed in developing countries, e.g., China, Brazil, and India, where the rapid development of agricultural and industrial activities has led to untreated wastewater discharges in lakes and rivers [29]. Likewise, the anthropogenic sources of heavy metals, such as mining activities, landfills, transportation, industrial discharge, are becoming major sources causing heavy metal contamination in lakes and reservoirs. Heavy metals, such as $\mathrm{Pb}, \mathrm{Cd}, \mathrm{Cr}, \mathrm{Hg}$, and As, are toxic, persistent, and accumulative in the food chain, which are a serious threat for both ecosystems and human health [30]. On top of this, diverse other contaminants enter lakes and reservoirs, such as human and animal drugs, respectively via wastewater discharge and agri/aqua cultural activities. Antibiotics are in this respect getting a lot of attention due to their direct effect on ecosystems, but also because of the generation of antibiotic-resistant strains in the environment, which can cause high risks for human health and cure.

Also related to health risk, the direct discharge of pathogens can lead to increased outbreaks of waterborne diseases related to recreational activities in small inland water bodies. Approximately 900,000 cases of illnesses and 900 deaths have occurred each year in the US due to the microbial 
contamination of drinking water and recreational activities [31]. Directly discharged wastewater effluent, diffuse sources from agriculture run-off are potential sources of high pathogen levels in these receiving waterbodies. Increasing recreational activities in these recreational waterbodies also lead to the increased risk of disease for participants, such as gastrointestinal, respiratory, ear, skin, and wound infections [32].

\subsection{Ecosystem Services}

From ancient times to the present, lakes and reservoirs have been used and even constructed for numerous functions, e.g., flood control, biodiversity, climate change mitigation, river flow regulation, hydropower supply, and water purification and storage. Due to these services, they often play a crucial role in social development, economic growth, food production, and human health. In fact, there are currently 8600 hydropower reservoirs which account for more than $16 \%$ of total worldwide electricity generation, corresponding to approximately $85 \%$ of global renewable electricity production [33]. Besides, 3700 new hydropower reservoirs are going to be built and operated to satisfy the need for food and water of the rapidly increasing population. As a result, hydroelectricity reservoirs become a crucial renewable energy source contributing considerably to water and energy development strategies in over 140 nations [34]. However, in contrast to the global bloom of hydropower reservoirs in the context of green and sustainable energy provision, also an increasing criticism on their profound environmental, ecological, and social impacts rises, making their value in reaching sustainable water and energy less straightforward. These impacts include habitat destruction, loss of habitat connectivity, methane emissions, dried riverbeds, extreme peak flows, invasive species outbreaks in the direct vicinity of these systems, as well as salt-water intrusion and disappearance of deltas downstream of these systems.

Moreover, fisheries and aquaculture are also an essential service of many lakes and reservoirs. In fact, they were the fastest growing sectors in the food industry with their global production increased by 40 times from the 1970s to 2010s and are expected to quintuple in the next 50 years [35]. In the Mekong Delta, pangasius production boosted from 4 million tons to 12 million tons between 2005 and 2008 because of the market accessibility in Europe and the US. Consequently, the seafood and processing industries in Vietnam rocketed, giving enormous opportunities for both international cooperation and smallholder farmers. However, this unsustainable expansion has caused the severe disappearance of mangrove ecosystems as approximately $50 \%$ of mangrove forest in Mekong delta in Vietnam were replaced by aquafarms despite the efforts of the Vietnamese government in intervening stricter laws and increasing enforcement [36].

Water treatment and storage are other major contributions of lakes and reservoirs, which have led to increased water availability for anthropogenic use. It is calculated that the total area for irrigation has risen from 40 million to 215 million ha between 1900 and 2000 with the cumulative storage capacity from 100 to $8300 \mathrm{~km}^{3}$ [37]. This unprecedented expansion was possible by the global bloom of hydropower reservoirs as currently over half of the world's global river systems are regulated by them [38]. Moreover, these inland waterbodies also provide a high capacity of self-purification thanks to high complexity with an interconnected web of biochemical reactions and complex hydraulic processes, and also resulted in the massive use of waste stabilization ponds for wastewater treatment [39]. This diverse treatment ability of these natural systems generated a major technology for wastewater treatment, which is very popular in the developing world due to their low cost, simple operation, and high robustness [40].

\subsection{Management and Policy}

All freshwater basins exploited by human activities demand management. This may involve regular monitoring to maintain and include efforts to enhance and protect the system as well as restore the impaired systems. In the case of lakes and reservoirs, due to their substantial economic benefits, there is an increasing requirement for management and policy for the sustainable exploitation of lakes and reservoirs, to sustain their beneficial uses over the long-term and more specifically meet the 
objectives related to the Sustainable Development Goals. From that point of view, the multifaceted factors of different stakeholders should be incorporated into the optimization and decision-making process. Consequently, large numbers of conflicting views are governing these systems and more transparent procedures are required to inform and convince stakeholders and authorities. As such, multicriteria decision analysis and computer-based decision support systems can provide a structured way to elicit and communicate individual preferences in a systems' context [41].

Noteworthy is that in contrast to substantial knowledge and understanding on water quality management in natural lakes as a result of long historical research, there is a shortage of insights into the characteristics of artificial reservoirs [1]. Despite the little distinctions between these two freshwater bodies in terms of limnology, their functions can be very different. Neglecting these differences can lead to inappropriate and unsustainable developments. In fact, a management policy should be site-specific for lakes and reservoirs, since they also serve different purposes leading to different priorities corresponding to different optimization methods in their management plans. However, there are certain aspects that need to address in the management policy. These aspects include aquatic species management with invasive species control, wildlife and fisheries management, nutrient budget, shore protection, water quality management, recreational and watershed management. Depending on the prioritized purposes and problems of the inland water body systems, site-specific actions, which put economic and time factors in their agenda, can be proposed.

Many efforts have been made for the restoration of lakes and reservoirs, in which there are many successful restoration projects, while several are reported as a failure [42]. One of the solutions for habitat disconnection is the use of fish bypasses. However, in case of severe physical degradation at the river basin level, undamming might be considered, as is reflected in its current controversial debate. In a short-term period, dam removal can increase the amount of sediment load leading to abrasion and toxicity to biota and habitats. However, it was also reported that the restoration of unregulated flow regimes improved significantly the biotic diversity due to the enrichment of free movement and spawning grounds [43]. Regarding eutrophication, due to the resilience of lake biochemical conditions, the reduction of external nutrient loading alone often led to unsuccessful restoration project [44]. To reinforce recovery, numerous biomanipulation methods have been integrated with physicochemical methods. Fish removal has become popular for a restoration project in Denmark and the Netherlands, which resulted in the improvement of visibility and less abundance of algae. However, the high concentration of mobile phosphorus in lake sediment can lead to the return of turbid conditions [42]. Moreover, the multifunctional exploitations of these stagnant waters challenge the determination of specific operation and restoration action and need multidisciplinary research and multi-stakeholder approaches [45].

\section{Challenges and Opportunities for the Sustainable Development of Lakes and Reservoirs}

\subsection{Emerging Threats and Challenges}

Anthropogenic activities, such as urbanization, industry, aquaculture, and watercourse alterations, remain ultimate threats to the sustainability of freshwater bodies. Almost any lake and reservoir on earth is subjected to different types of pressures, characterized by complicated links between each other, and generating a vast array of long-term costs. Moreover, the Earth's climate is changing and expected to continue to change in the future, gradually transforming the Earth's ecosystems. The scale of climate change impact on inland water bodies is global but the impacts can be seen locally and differently from place to place. Geographic location, elevation, and morphometry are crucial factors determining the effects of climate change on lakes and reservoirs. In tropical and arid regions, small inland water bodies encounter the changes in water level and conductivity as a result of the shifts in water balance and evaporation rate [46]. In temperate and boreal zones, the variation of precipitation can change the nutrients import of freshwater bodies. Interestingly, these water bodies and climate change have a double relationship. On the one hand, the impact of climate change on global temperature, sediment 
transport, temporal precipitation, and the intensity of floods and droughts affect the sustainable development of lakes. On the other hand, they are themselves both natural and artificial sources that can substantially contribute to climate change via their degrading organic carbon storage, and related carbon dioxide $\left(\mathrm{CO}_{2}\right)$ and methane $\left(\mathrm{CH}_{4}\right)$ emissions [7-10].

Another emerging threat for lake sustainability in future decades is the ever-increasing number of emerging contaminants as a result of the development of technologies adding more products and chemicals into the environment [47]. These surreptitious contaminants are new compounds with little environmental regulation and whose impacts are still not completely clear [48]. They range from personal care products and illicit drugs to endocrine disrupting compounds, which can pose a serious threat to both the aquatic ecosystem and human health [49]. More importantly, the presence of microplastics and antimicrobial resistance (AR) in lakes are increasing in developing countries as a result of the widespread use of these products [50,51]. Agriculture, aquaculture and livelihood developments, caused a high level of AR in surface water systems, consequently, causing health problems to water users [52].

\subsection{Opportunities for Sustainable Development of Lakes and (Hydropower) Reservoirs}

Since lakes and reservoirs contribute significantly to freshwater availability and use, their sustainability needs to be made central to the success of the Sustainable Development Goals (SDGs) [53]. To keep the security of the water resource under the pressure of unprecedented population growth and increasing climate change impacts, sustaining a globally well-functioning water cycle is a main objective and challenge. Consequently, the development of lakes and reservoirs must support sustainable access to adequate quantities and qualities of numerous benefits to human society, environmental well-being, and economic welfare.

To illustrate the whole picture of publications related to the sustainable development of lakes and reservoirs, three research lines were made, including (1) Status; (2) Ecosystem services; (3) Management and Policy (Figure 1). These three research lines cover 18 major research topics, which play important roles in their sustainable development. The details of the topics and their search query in the Web of Science can be found in Table S1 in Supplementary Material A. We identified the keyword queries for each research topic based on our expertise and previous bibliometric analyses whose topics are comparable [39,54-69]. Regarding the status, a high number of publications has been dedicated to urgent issues in environmental and human health, i.e., emerging contaminants and waterborne diseases. Besides, biodiversity and climate change have been increasingly investigated in lakes in line with trends in species extinction and the global biodiversity crisis. Climate change impacts on lake systems have received more scientific attention in recent years. Eutrophication and heavy metals remain constant problems in these stagnant waters due to the long impact of intensive agricultural and industrial activities.

As one of the key renewable energy resources in the near future, hydropower has attracted considerable attention from both studies to business areas. Due to recent findings on their impacts on the river and estuarine ecosystems and their contributions to climate change via greenhouse gas emissions, the eventual contribution of this renewable energy resource to the future clean energy are increasingly questioning. Besides flood control as a constant benefit of lakes from ancient times, fisheries and drinking water are increasingly exploited with the growing needs of the expanded populations. Because of these substantial economic benefits, higher requirements for management and policy are needed. In fact, 4000 publications have been dedicated to the operation and management of lakes and reservoirs, reflecting the growing benefits of control on lakes and reservoirs to warrant environmental and human health and social economic welfare. Particularly, policy development, laws and regulations have been increasingly explored in recent years. 


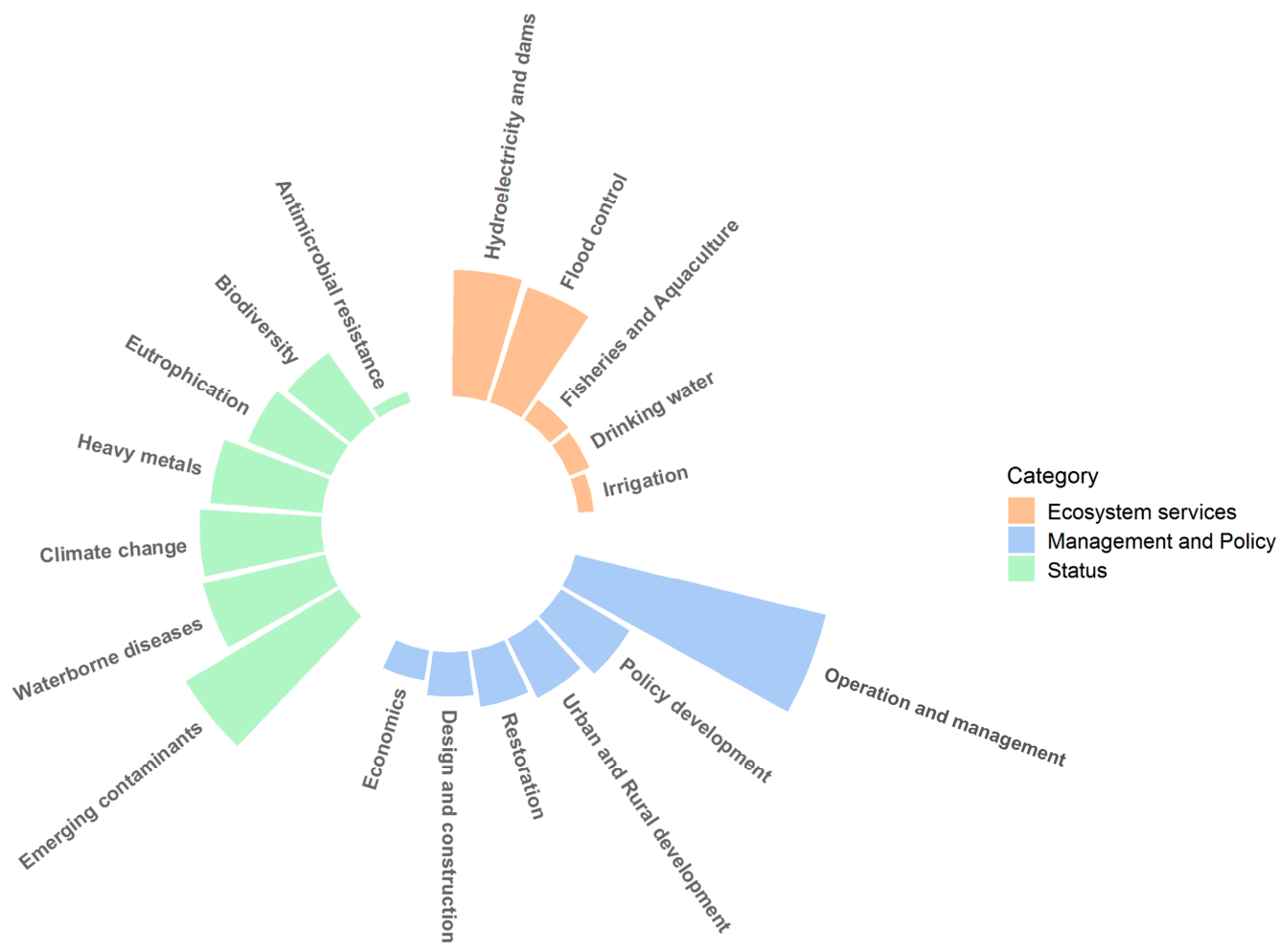

Figure 1. The number of publications in three research lines with topics related to the sustainable development of lakes and reservoirs from 2009 to 2018. The data were extracted from the online database of the Science Citation Index Expanded (SCI-Expanded) in the Web of Science on 24 January 2019. More information on the methodology of the bibliometric analysis can be found in Supplementary Material A.

\section{The Interlinkages between the Sustainable Development of Lakes and Reservoirs and the SDGs}

\subsection{Sustainable Development Goals of the 2030 Agenda}

The 2030 Agenda for Sustainable Development is a plan of action for people, planet, and prosperity with a principal objective of leaving no one behind [70]. This Agenda contains 17 Sustainable Development Goals (SDGs), 169 targets, and 232 indicators, which stimulate actions over the next 15 years in areas of critical importance for humanity and the planet with the specific aim of eradicating extreme poverty and hunger [70]. The SDGs integrate the 5Ps: people, planet, prosperity, peace, and partnership (Figure 2), which highlight the interdependence of the targets and the requirement of integrated and coordinated implementation of the goals [71]. Despite not being legally binding, the Agenda developed a Global Indicator Framework, which is being used in many countries to achieve their clean, green and sustainable future. However, policymakers face the challenge of implementing the SDGs simultaneously due to numerous interlinkages, including both synergy and potential trade-off, within and between these goals [72]. Understanding these interlinkages allows countries to target and implement their policies efficiently by connecting synergies while managing potential conflicts [73]. However, these interlinkages currently have a weak conceptual and scientific underpinning, highlighting an urgent need for holistic and comprehensive approaches and tools that can analyze of the nature and strengths of these interactions and how they affect policy and implementation [72]. A noticeable example is the study of UN Water [74] on the central role of water and sanitation to describe the links and interdependencies between the targets of SDG 6 and other Goals. Particularly, the role of water and sanitation in the development of three dimensions, i.e., economic, social, and environmental dimensions, is investigated, highlighting the importance of mainstreaming water and sanitation in the policies and plans of other sectors. From this perspective, we performed 
a critical analysis of the interlinkages between SDG targets for the sustainable development of lakes and reservoirs around the world by taking a closer look at a single indicator. Particularly, the interactions between two sides are taken into account, i.e., the roles of lakes and reservoirs in achieving these 17 SDGs and the impact of the potential actions for these achievements on the sustainable development of lakes and reservoirs. This descriptive analysis with the support of scientific evidence can function as the guideline for decision makers on the critical linkages of the SDGs and the sustainability of lakes and reservoirs.
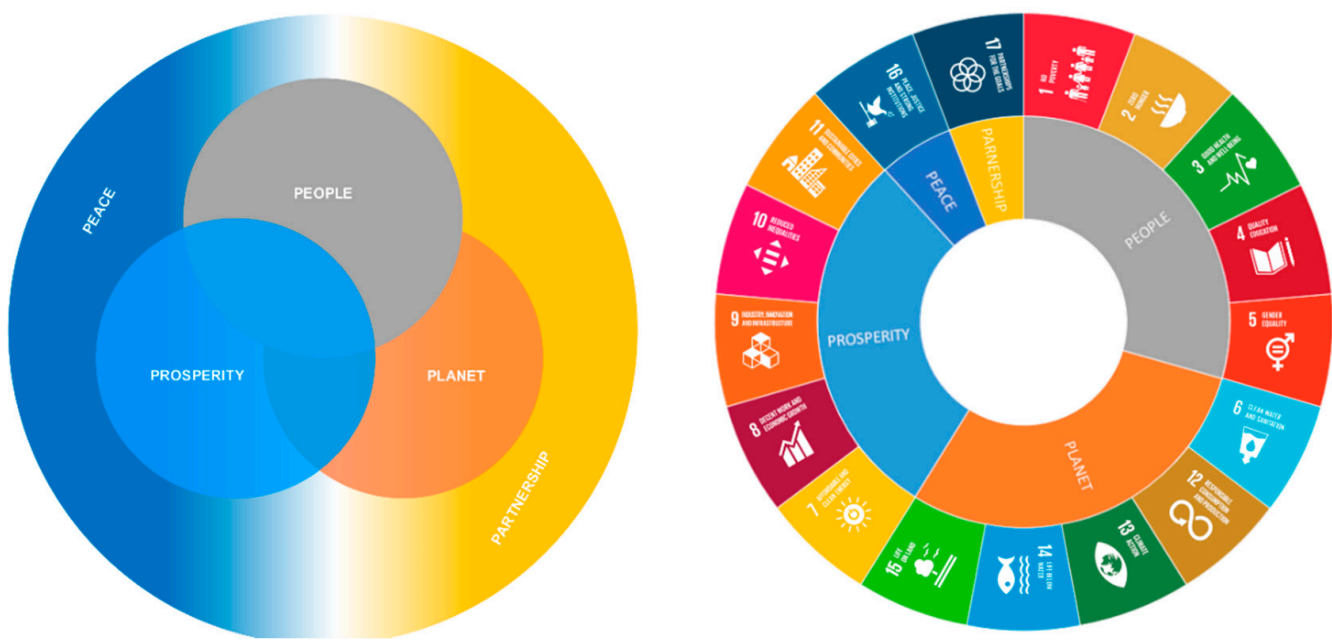

Figure 2. The 5Ps concept in the 2030 Agenda for Sustainable Development. The 5Ps concept includes People (Goals 1-5), Planet (Goals 6, 12-15), Prosperity (Goals 7-11), Peace (Goal 16), and Partnership (Goals 17).

\subsection{The Interlinkages between the Sustainable Development of Lakes and Reservoirs and the SDGs}

Figure 3 shows the summary of the interlinkages between the necessary implementation for achieving a better and more sustainable future of lakes and reservoirs and the actions in the framework of the SDGs. Two types of interlinkages are concerned, i.e., synergy and potential conflict. While the synergic interlinkages demonstrate two actions sharing a mutually supportive relationship, potential conflicts indicate the potential trade-offs and/or constraints of two actions on each other. These interlinkages can be direct or indirect. While the direct interlinkages include the SDGs that refer explicitly to inland water bodies or perceptions involved directly with lakes and reservoirs, the indirect interlinkages show the implicit effects of the actions to achieve both sustainable development on the others. To avoid exhaustive description, Table 1 shows an overview of only direct interlinkages. The details of indirect interlinkages can be found in Table S2 in the Supplementary Material B. As shown in Table 1, the actions to achieve the sustainable development of lakes and reservoirs strongly interlink with nine SDGs splitting in three Ps: (1) People (Goals 1, 2, and 3); (2) Planet (Goals 6, 13, 14, and 15); (3) Prosperity (Goals 7 and 8). Although synergies are abundant in most of the interlinkages, potential conflicts can occur between lake sustainability and the SDGs. Particularly, the actions for achieving lake sustainability mainly have positive links with the SDGs related to environmental dimensions (Goals 6, 13, 14, and 15) as they are mutually reinforcing each other. On the other hand, besides the positive aspects, these actions have potential conflicts with the SDGs related to social and economic dimensions, i.e., SDG 1-No poverty, SDG 2-End hunger, SDG 3-Good health and well-being, and SDG 8-Decent work and economic growth. Although the majority of the economic-driven targets aim to dissociate environmental deprivation from economic growth, the indirect impacts of human activity to obtain the economic growth can be extensive on lake sustainability as this was the case in the past. A noticeable example is that the correlation between the higher amount of untreated wastewater and the increasing per capita income was found in higher pollution-generating economic activities [54]. 
Table 1. Overview of direct interlinkages between the sustainable development of lakes and reservoirs and the SDGs.

\begin{tabular}{|c|c|c|c|}
\hline SDGs & Type of the Interlinkages & Roles of Lakes and (Hydropower) Reservoirs & Impact of Potential Actions on Lake Sustainability \\
\hline SDG 1-No poverty & Direct potential conflict & $\begin{array}{l}\text { - Target 1.1 to 1.3: Benefits from lake ecosystem services and } \\
\text { hydropower reservoirs are vast in terms of both water } \\
\text { resources and sustainable energy production [75]. } \\
\text { Target 1.4: Moreover, the preservation of lakes as a major } \\
\text { inland water resource is essential to "ensure that all men } \\
\text { and women ... have equal rights to basic services ... } \\
\text { natural resources" [76]. } \\
\text { Target 1.5: Similarly, the freshwater bodies provide a } \\
\text { substantial buffer capacity for flood control and drought } \\
\text { prevention as such "reducing vulnerability to } \\
\text { climate-related extreme events... and environmental } \\
\text { shocks and disasters" [53]. }\end{array}$ & $\begin{array}{l}\text { - A complex relationship between economic well-being and the sustainability } \\
\text { of water resources because of two reasons. } \\
\text { - Firstly, the economic well-being involves in many different sectors that, in } \\
\text { turn, affect or be affected by the water sector. } \\
\text { Secondly, water is an essential component of an economic system. } \\
\text { According to The United Nations [77], } 80 \% \text { of all jobs globally are } \\
\text { dependent on sustainably managed water resources and water-related } \\
\text { services, including sanitation and wastewater services. } \\
\text { - However, the indirect impacts to obtain economic growth for achieving SDG } \\
1 \text { can be severe on lake sustainability as this was the case in the past [78]. }\end{array}$ \\
\hline SDG 2-End hunger & $\begin{array}{l}\text { Both direct potential conflict and } \\
\text { synergy }\end{array}$ & $\begin{array}{l}\text { - Target 2.3: As one of the main freshwater bodies being } \\
\text { exploited for irrigation, lakes and reservoirs play an } \\
\text { essential role to "double the agricultural productivity and } \\
\text { incomes of small-scale food producers". } \\
\text { Many dry regions became suitable for agriculture due to } \\
\text { the availability of irrigation systems, which were derived } \\
\text { from the construction of hydropower dams [79]. In fact, } \\
\text { the total area, which has been watered for agriculture, has } \\
\text { increased from } 40 \text { Mha in the } 1900 \text { s to } 215 \text { Mha in } 2000 \text { [37]. }\end{array}$ & $\begin{array}{l}\text { - Targets } 2.3 \text { and } 2.6 \text {, focusing on a sustainable implementation strategy in } \\
\text { agricultural policies, can increase the efficiency of water use and } \\
\text { productivity, creating more food without expansion or intensification of } \\
\text { cultivated land, leading to the reduction of water pollution in the receiving } \\
\text { water bodies. } \\
\text { Target 2.4, aiming to achieve the "double the agricultural productivity" in a } \\
\text { sustainable way, can promote the development of environmentally } \\
\text { friendly technology. } \\
\text { Conversely, the increase of agricultural activities can lead to a higher } \\
\text { amount of pollutants, including nutrients, pesticides, herbicides, and other } \\
\text { emerging contaminants, to the waterbodies [80]. }\end{array}$ \\
\hline SDG 3-Good health and well-being & $\begin{array}{l}\text { Both direct potential conflict and } \\
\text { synergy }\end{array}$ & $\begin{array}{l}\text { - Targets } 3.3 \text { and 3.9: With substantial water storage capacity } \\
\text { for drinking water and recreation activities, the sustainable } \\
\text { development of lakes and reservoirs is essential in } \\
\text { reducing waterborne diseases, deaths, and illnesses related } \\
\text { to water pollution and contamination. } \\
\text { However, lakes and ponds are the locations that have the } \\
\text { second highest number of outbreaks of waterborne } \\
\text { diseases, occupying approximately } 40 \% \text { of the total } \\
\text { number of outbreaks occurring between } 1951 \text { and } 2006 \text { [81]. } \\
\text { Lack of sanitation systems, diffused sources from } \\
\text { agriculture run-off are the main sources of high pathogen } \\
\text { levels in lakes and reservoirs [82]. }\end{array}$ & $\begin{array}{l}\text { - In order to achieve the improvement of health care systems, better quality } \\
\text { water resource should be obtained in tandem. } \\
\text { However, a trade-off of increasing using antibiotics to eliminate diseases } \\
\text { (targets } 3.1,3.3,3.4,3.8,3 . b) \text { can lead to the increase of antimicrobial } \\
\text { resistance (AR). }\end{array}$ \\
\hline
\end{tabular}


Table 1. Cont.

\begin{tabular}{|c|c|c|c|}
\hline SDGs & Type of the Interlinkages & Roles of Lakes and (Hydropower) Reservoirs & Impact of Potential Actions on Lake Sustainability \\
\hline SDG 6-Clean water and sanitation & Direct synergy & $\begin{array}{l}\text { - There are strong interlinkages between SDG } 6 \text { and the } \\
\text { sustainability of lakes and reservoirs. } \\
\text { - Targets 6.1 and 6.4: "safe and affordable drinking water for } \\
\text { all" and "integrated water resources management at all } \\
\text { levels" are also directly related to the development of lakes } \\
\text { and reservoirs. } \\
\text { - Target 6.6: "By 2020, protect and restore water-related } \\
\text { ecosystems, including ... lakes". This was due to the fact } \\
\text { that many rivers and lakes have been drying out, leading } \\
\text { to much less water, less water-related habitat and } \\
\text { consequently less provision of ecosystem services [83]. }\end{array}$ & $\begin{array}{l}\text { - Most of the actions to achieve the SDG } 6 \text { are beneficial to the sustainable } \\
\text { development of lakes and reservoirs. } \\
\text { - Targets } 6.3 \text { and } 6.4 \text { : "improve water quality by reducing pollution" and } \\
\text { "ensure sustainable withdrawals and supply of freshwater to address water } \\
\text { scarcity", will mitigate the pressure of overexploitation and water pollution } \\
\text { in the inland freshwater bodies [84]. }\end{array}$ \\
\hline SDG 7-Affordable and clean energy & Direct synergy & $\begin{array}{l}\text { - Main objectives of targets } 7.2 \text { and } 7.3 \text { are to increase the } \\
\text { proportion of renewable energy in the total final energy } \\
\text { consumption. As such, the global bloom of hydropower } \\
\text { reservoirs contributes significantly to the achievement of } \\
\text { this target. } \\
\text { - Currently, as important renewable energy, hydropower } \\
\text { plants (HPs) account for more than } 16 \% \text { of total worldwide } \\
\text { electricity generation, corresponding to approximately } 85 \% \\
\text { of global renewable electricity production [33]. } \\
\text { Moreover, HPs are designed and operated to provide } \\
\text { services beyond electricity generation, such as water } \\
\text { supply, flood and drought management, irrigation, } \\
\text { navigation, fisheries, and recreational activities [75]. }\end{array}$ & $\begin{array}{l}\text { - Target 7.a "advanced and cleaner fossil-fuel technology, and promote } \\
\text { investment in energy infrastructure and clean energy technology" directly } \\
\text { contribute to the sustainability of hydropower reservoirs. } \\
\text { After the golden period of large HPs, its profound environmental and social } \\
\text { impacts have been increasingly evident, creating intense debates over its } \\
\text { real values [85]. } \\
\text { A countertrend towards small HP projects has growingly appeared since } \\
\text { they can provide similar benefits but with lower socioecological impacts } \\
\text { due to the less occupied space and infrastructure requirements. In fact, } \\
\text { many small HPs have been deployed in Europe where there are } \\
\text { approximately } 10 \text { times more small HPs than large HPs [86]. }\end{array}$ \\
\hline
\end{tabular}

- Water quality and quantity are essential for

conomic development.

- Lakes have been exploited for industrialization and intensive agriculture over long periods. As a result, eutrophication and heavy metal contamination already

SDG 8-Decent work and economic Both direct potential conflict and occurred in lakes since the 1930 s $[87,88]$.

Target 8. a about "increase aid ... for Trade-related Technical Assistance to Least Developed Countries" benefit the efficiency of water usage and ecosystem preservation in lake systems.

- Target 8.9 can promote sustainable tourism can encourage sustainable exploitation of the recreational services of lake

Targets 8.4 and 8.9 try to dissociate environmental deprivation from economic growth by employing clean and environmentally

Targets 8.1 and 8.3 do not explicitly include the sustainable management of natural resources [74]. This highlights the need for SDGs within economic to implemented in an integrated fashion to avoid any potential conflict with the
lakes and reservoirs [74]. 
Table 1. Cont

SDGs

Direct synergy Type of the Interlinkages

Roles of Lakes and (Hydropower) Reservoirs

- Freshwater bodies and climate change show a double relationship [89].

- Hydropower reservoirs are a central renewable energy resource contribute to climate change mitigation [90].

Lakes and reservoirs are one of the main regulators of carbon cycling and climate change [91,92].

- They play a crucial role at preventing extreme climate

events, such as floods, or snow and glacier melt [2].

To achieve target 13.2, the role of lakes and reservoirs should be integrated into national policies, strategies an and low greenhouse gas emissions development.

- Analogous global problems occur in both inlan heavy metal contamination, microplastics, and species distinctions, due to their identical anthropogenic press
and interconnections via river run-off systems [101].

SDG 14-Life below water

Direct synergy

- Lower freshwater flux with higher pollutant concentrations to the coastal area causes difficulty of achieving the targe pollution of all kinds, in particular from land-based activities, including marine debris and nutrient pollution".

Impact of Potential Actions on Lake Sustainability

- On the other hand, due to climate change, the alteration of river discharge will affect water availability and regularity, and energy generation $[93,94]$. However, climate change will not lead to significant changes in the globa hydropower generation $[90,93,95-97]$

Warming of lake water has synergistic effects with nutrient enrichment, web structure [98-100]. Connobacteria it eutrophic lakes, and alters food of algal bloom the change in water clarity, assemblages of plankton and fish communities [100].

- The increasing temperature has had a significant impact on top predators, such as pike (Esox lucius), causing the alteration in the topological architecture of food webs and whole ecosystem sensitivity to climate variation [13]

- Target 14.1, aiming to protect marine ecosystems, the prevention and reduction of pollution from land-based activities are essential. As such increasing the water quality from inland water systems should be prioritized to achieve a heal fhy life below wate

However, a potential trade-off between

The main aim of targets 14.4 and 14.6 is to avoid overfishing and illegal more pressures on freshwater fishes in lakes and reservoirs.

- To avoid this potential conflict, an integrated assessment involving terrestrial, freshwater and marine protected areas promises more effective conservation outcomes than disconnected reserve [11].

- Inland water bodies and terrestrial ecosystems are of paramount importance for many complex biogeochemical cycles, such as the carbon cycle, the water cycle, the nitrogen cycle, and the nutrient cycle [102,103].

- Target 15.1: the flux of energy, elements, and compound between two systems are sophisticated, in which aquatic subsidies have a high capacity to fuel terrestrial food we which depends on the number of their allochthonou inputs from the terrestrial biosphere [104,105].

SDG 15-Life on land

Target 15.3, aiming to combat desertification and reco land affected by desertification, drought, and floods,

Sustainable water use of inland water bodies is essential.
Targets 15.4 and 15.5: strong food web linkages between lakes and lands highlight the needs of integration of their
conservations in terms of biodiversity and natural habitats.

- Inputs of organic carbon and compounds from terrestrial biosphere can go beyond levels supported by lake photosynthesis, hence, changing the metabolisms of the lakes via direct and indirect effects create complex

interactions in food chains between land and freshwater biospheres [106]

- Target 15.1 shows the importance of protecting both terrestrial and freshwater biodiversity in parallel.

- Target 15.8 focuses on the prevention and control of invasive species, which need to be implemented in both inland water bodies and terrestrial ecosystems as the life cycle of many species involves both ecosystems [107]. 
The contributions of lakes and reservoirs in support to the achievement of the Sustainable Development Goals (SDGs)

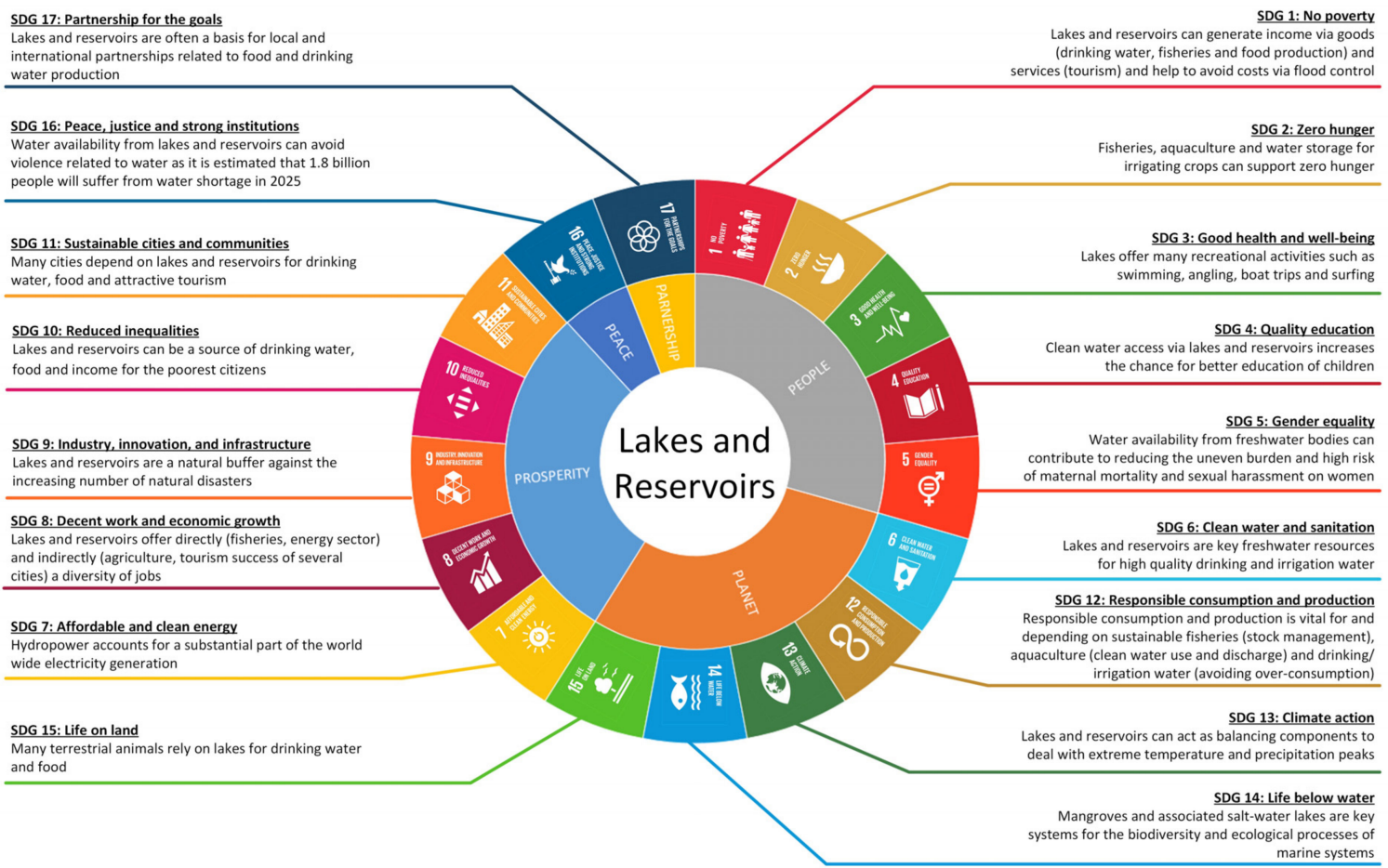

Figure 3. The summary of the contributions of lakes and reservoirs to support the achievement of the Sustainable Development Goals (SDGs).

\subsection{Indicators of the Sustainable Development of Lakes and Reservoirs}

After the assessment of the interlinkages between the SDGs and the sustainable development of lakes and reservoirs, we propose a list of indicators to monitor the sustainable development of lakes and reservoirs. The list is built, based on their strong synergies with the abovementioned SDGs with the main focus on the environmental dimensions, i.e., SDGs 6, 13, 14, and 15, and SDG 7 with regards to renewable energy from hydropower reservoirs. A total of 22 proposed indicators were based on the 232 indicators developed by Inter-Agency and Expert Group on Sustainable Development Goal Indicators and adopted by the General Assembly at its seventy-first session in July 2017. These indicators are measurable with their values that can represent global, regional and subregional aggregates (Table 2). According to the Secretary-General's annual report on "Progress towards the Sustainable Development Goals", these indicators are calculated from data from national statistical systems, compiled by international agencies which are vital for evidence-based decision-making and the full implementation of the 2030 Agenda. As such, our proposed indicators scaled up to lake and reservoir systems can be used to monitor the sustainable development of lakes and reservoirs. Particularly, these indicators focus on urgent topics, i.e., water quality, eutrophication and (micro) plastics, fisheries, biodiversity, biological invasions, eco-friendly dams, and (inter) national and local management. As mentioned in the SDGs that their indicators should be implemented as an indivisible whole', the same principle is applied to the proposed indicators for the sustainable development of lakes and reservoirs. To target these indicators, the policymakers can formulate required actions that need to be integrated to the practical measures from the other SDGs, such as land [108], climate [109], ocean [110]. Noteworthy is that the situation of individual countries/regions may vary significantly, hence one should pay extra attention to the aggregated data despite its convenient way to track the progress of sustainable development. Besides, since the proposed indicators based on the 232 indicators that are still undergoing methodological development by the United Nations, updating information is necessary to keep track of the progress on SDG implementation. 
Table 2. Proposed indicators for monitoring the sustainable development of lakes and reservoirs.

\begin{tabular}{|c|c|c|c|}
\hline No. & Proposed Indicators & Related Targets & Related SDGs \\
\hline 1 & $\begin{array}{c}\text { Proportion of wastewater safely treated before being } \\
\text { discharged into lakes and reservoirs }(\%)\end{array}$ & 6.3 .1 & \multirow{8}{*}{$\begin{array}{l}\text { SDG 6-Clean water } \\
\text { and sanitation }\end{array}$} \\
\hline 2 & $\begin{array}{l}\text { Proportion of lakes and reservoirs with good ambient water } \\
\text { quality }(\%)\end{array}$ & 6.3 .2 & \\
\hline 3 & $\begin{array}{l}\text { Level of water stress: freshwater withdrawal as a proportion of } \\
\text { available freshwater resources }(\%)\end{array}$ & 6.4 .2 & \\
\hline 4 & $\begin{array}{l}\text { Proportion of lake and reservoir basins with an operational } \\
\text { arrangement for water cooperation (\%) }\end{array}$ & 6.5 .2 & \\
\hline 5 & Nationally derived extent of lakes and reservoirs $\left(\mathrm{km}^{2}\right)$ & \multirow{3}{*}{6.6 .1} & \\
\hline 6 & Nationally derived quality of lakes and reservoirs (\%) & & \\
\hline 7 & $\begin{array}{l}\text { Nationally derived quantity of lakes and reservoirs (million of } \\
\qquad \mathrm{m}^{3} \text { per annum) }\end{array}$ & & \\
\hline 8 & $\begin{array}{l}\text { Proportion of local administrative units with established and } \\
\text { operational policies and procedures for participation of local } \\
\text { communities in lake and reservoir management }(\%)\end{array}$ & 6.b.1 & \\
\hline 9 & $\begin{array}{l}\text { Renewable energy from eco-friendly hydropower reservoirs } \\
\text { shares in the total energy consumption }(\%)\end{array}$ & 7.2 .1 & $\begin{array}{l}\text { SDG 7-Affordable } \\
\text { and clean energy }\end{array}$ \\
\hline 10 & $\begin{array}{l}\text { Number of countries with (inter) national and local disaster risk } \\
\text { reduction strategies involving the roles of lakes and reservoirs } \\
\text { (number) }\end{array}$ & 13.1.1 & $\begin{array}{l}\text { SDG } 13-\text { Climate } \\
\text { action }\end{array}$ \\
\hline 11 & $\begin{array}{l}\text { Index of lake eutrophication and floating plastic debris density } \\
\text { (number) }\end{array}$ & 14.1.1 & \multirow{6}{*}{$\begin{array}{l}\text { SDG 14-Life below } \\
\text { water }\end{array}$} \\
\hline 12 & $\begin{array}{l}\text { Proportion of fish stocks within biologically sustainable levels } \\
\text { in lakes and reservoirs (not overexploited) }(\%)\end{array}$ & 14.4.1 & \\
\hline 13 & $\begin{array}{l}\text { Coverage of protected areas in relation to lakes and reservoirs } \\
\text { (Exclusive Economic Zones) }(\%)\end{array}$ & 14.5 .1 & \\
\hline 14 & $\begin{array}{l}\text { Progress by countries in the degree of implementation of } \\
\text { international instruments aiming to combat illegal, unreported } \\
\text { and unregulated fishing in lakes and reservoirs (level of } \\
\text { implementation: } 1 \text { lowest to } 5 \text { highest) }\end{array}$ & 14.6 .1 & \\
\hline 15 & $\begin{array}{l}\text { Proportion of total research budget allocated to research in the } \\
\text { field of lakes and reservoirs (\%) }\end{array}$ & 14.a.1 & \\
\hline 16 & $\begin{array}{l}\text { Degree of application of a legal/regulatory/policy/institutional } \\
\text { framework which recognizes and protects access rights for } \\
\text { small-scale fisheries (level of implementation: } 1 \text { lowest to } 5 \\
\text { highest) }\end{array}$ & 14.b.1 & \\
\hline 17 & $\begin{array}{l}\text { Average proportion of Freshwater Key Biodiversity Areas } \\
\text { (KBAs) covered by protected areas }(\%)\end{array}$ & 15.1.2 & \multirow{6}{*}{ SDG 15-Life on land } \\
\hline 18 & $\begin{array}{l}\text { Proportion of lake and reservoir area with a long-term } \\
\text { management plan }(\%)\end{array}$ & 15.2.1 & \\
\hline 19 & $\begin{array}{l}\text { Proportion of forest area within legally established protected } \\
\text { areas (\%) }\end{array}$ & & \\
\hline 20 & $\begin{array}{c}\text { Proportion of lakes and reservoirs that is degraded over total } \\
\text { area of lakes and reservoirs (\%) }\end{array}$ & 15.3 .1 & \\
\hline 21 & Red List Index for freshwater species (number) & 15.5 .1 & \\
\hline 22 & $\begin{array}{l}\text { Proportion of countries adopting relevant national legislation } \\
\text { and adequately resourcing the prevention or control of invasive } \\
\text { alien species in lakes and reservoirs (\%) }\end{array}$ & 15.8 .1 & \\
\hline
\end{tabular}

\section{Conclusions}

From ancient times to the present, lakes and reservoirs have been exploited for numerous functions, e.g., flood control, biodiversity, climate change mitigation, river flow regulation, hydropower supply, and water purification and storage. As such, they play crucial roles in social development, economic 
growth, and human health. However, due to human overexploitation and emerging global threats, such as biological invasions, climate change, land-use intensification, and water depletion, their future is at risk. Eutrophication has led to degradation of lake ecosystems and biodiversity in approximately $40 \%$ of the total number of lakes worldwide while $83 \%$ of freshwater species have been disappeared since 1970. Furthermore, 900,000 cases of illnesses occur in the US alone due to microbial contamination from activities related to lakes and reservoirs each year.

Because of this threatening situation of lakes and reservoirs, together with the need to integrate their roles in the sustainable development across the economic, social and environmental dimensions, their interlinkages with the SDGs were investigated. Particularly, the roles of lakes and reservoirs in achieving these 17 SDGs and the impact of the potential actions for these achievements on the sustainable development of lakes and reservoirs were analyzed. It appears that the actions to achieve the sustainable development of lakes and reservoirs have strong interlinkages with nine SDGs, split in three Ps: (1) People (Goals 1, 2, and 3); (2) Planet (Goals 6, 13, 14, and 15); (3) Prosperity (Goals 7 and 8 ). The actions for achieving lake sustainability mainly have positive links with the SDGs related to environmental dimensions (Goals 6, 13, 14, and 15) as they are mutually reinforcing each other. In contrast, these actions have potential conflicts the possible activities to achieve the SDGs related to social and economic dimensions, Goals 1,2,3 and 8. Based on these interlinkages, we proposed 22 indicators that cover five main areas related to five SDGs, i.e., Goals 6, 7, 13, 14, and 15. More specifically, these indicators focus on urgent topics, i.e., water quality, eutrophication and (micro) plastics, fisheries, biodiversity, biological invasions, eco-friendly dams, and (inter) national and local management. With these indicators, policymakers are able to keep track of the development of lakes and reservoirs and, hence, decide on holistic and multidimensional management and policies for the sustainable future of lakes and reservoirs which, following the definition of Brundtland Commission [111] on sustainability, is to "meet the needs of the present without compromising the ability of future generations to meet their own needs".

Supplementary Materials: The following are available online at http:/www.mdpi.com/2073-4441/11/7/1462/s1. Table S1: Research topics and their search query in the Web of Science. The search query in each research topic is combined with the search query for lakes or reservoirs to search the publications in that research line under the context of lakes or reservoirs, respectively. Table S2: Overview of indirect interlinkages between the sustainable development of lakes and reservoirs and the SDGs.

Author Contributions: Both conceived the ideas and structure of the manuscript, and contributed to writing and editing of text.

Funding: This research was performed in the context of the VLIR Ecuador Biodiversity Network project. This project was funded by the Vlaamse Interuniversitaire Raad-Universitaire Ontwikkelingssamenwerking (VLIR-UOS), which supports partnerships between universities and university colleges in Flanders and the South.

Acknowledgments: Long Ho is supported by the special research fund (BOF) of Ghent University.

Conflicts of Interest: The authors declare no conflict of interest.

\section{References}

1. Jørgensen, S.E. Lake and Reservoir Management; Elsevier: Amsterdam, The Netherlands, 2005.

2. Schallenberg, M.; de Winton, M.D.; Verburg, P.; Kelly, D.; Hamill, K.; Hamilton, D. Ecosystem services of lakes. In Ecosystem Services in New Zealand-Conditions and Trends; Manaaki Whenua Press: Lincoln, New Zealand, 2013; pp. 203-225.

3. Ricciardi, A.; MacIsaac, H. Impacts of biological invasions on freshwater ecosystems. In Fifty Years of Invasion Ecology; Wiley-Blackwell: Hoboken, NJ, USA, 2011.

4. Ricciardi, A.; Neves, R.J.; Rasmussen, J.B. Impending extinctions of north american freshwater mussels (unionoida) following the zebra mussel (dreissena polymorpha) invasion. J. Anim. Ecol. 1998, 67, 613-619. [CrossRef]

5. Moyle, P.B. The frankenstein effect: Impact of introduced fishes on native fishes in north america. In Fish Culture in Fisheries Management; Amer Fisheries Society: Bethesda, MD, USA, 1986. 
6. Allendorf, F.W. Ecological and genetic-effects of fish introductions-synthesis and recommendations. Can. J. Fish. Aquat. Sci. 1991, 48, 178-181. [CrossRef]

7. Cole, J.J.; Caraco, N.F. Carbon in catchments: Connecting terrestrial carbon losses with aquatic metabolism. Mar. Freshw. Res. 2001, 52, 101-110. [CrossRef]

8. Sobek, S.; Algesten, G.; Bergstrom, A.K.; Jansson, M.; Tranvik, L.J. The catchment and climate regulation of pco(2) in boreal lakes. Glob. Chang. Biol. 2003, 9, 630-641. [CrossRef]

9. Bastviken, D.; Cole, J.; Pace, M.; Tranvik, L. Methane emissions from lakes: Dependence of lake characteristics, two regional assessments, and a global estimate. Glob. Biogeochem. Cycles 2004, 18. [CrossRef]

10. Raymond, P.A.; Hartmann, J.; Lauerwald, R.; Sobek, S.; McDonald, C.; Hoover, M.; Butman, D.; Striegl, R.; Mayorga, E.; Humborg, C.; et al. Global carbon dioxide emissions from inland waters. Nature 2013, 503, 355-359. [CrossRef] [PubMed]

11. Arthington, A.H.; Dulvy, N.K.; Gladstone, W.; Winfield, I.J. Fish conservation in freshwater and marine realms: Status, threats and management. Aquat. Conserv. 2016, 26, 838-857. [CrossRef]

12. IPCC. Climate Change 2014 Impacts, Adaptation, and Vulnerability Part A: Global and Sectoral Aspects; Cambridge University Press: New York, NY, USA, 2014; p. 1132.

13. Edeline, E.; Groth, A.; Cazelles, B.; Claessen, D.; Winfield, I.J.; Ohlberger, J.; Vollestad, L.A.; Stenseth, N.C.; Ghil, M. Pathogens trigger top-down climate forcing on ecosystem dynamics. Oecologia 2016, 181, 519-532. [CrossRef]

14. Sanderson, E.W.; Jaiteh, M.; Levy, M.A.; Redford, K.H.; Wannebo, A.V.; Woolmer, G. The human footprint and the last of the wild. Bioscience 2002, 52, 891-904. [CrossRef]

15. Keesstra, S.; Mol, G.; de Leeuw, J.; Okx, J.; Molenaar, C.; de Cleen, M.; Visser, S. Soil-related sustainable development goals: Four concepts to make land degradation neutrality and restoration work. Land 2018, 7, 133. [CrossRef]

16. Verpoorter, C.; Kutser, T.; Seekell, D.A.; Tranvik, L.J. A global inventory of lakes based on high-resolution satellite imagery. Geophys. Res. Lett. 2014, 41, 6396-6402. [CrossRef]

17. Harrison, I.; Abell, R.; Darwall, W.; Thieme, M.L.; Tickner, D.; Timboe, I. The freshwater biodiversity crisis. Science 2018, 362, 1369. [PubMed]

18. Downing, J.A.; Prairie, Y.T.; Cole, J.J.; Duarte, C.M.; Tranvik, L.J.; Striegl, R.G.; McDowell, W.H.; Kortelainen, P.; Caraco, N.F.; Melack, J.M.; et al. The global abundance and size distribution of lakes, ponds, and impoundments. Limnol. Oceanogr. 2006, 51, 2388-2397. [CrossRef]

19. Lehner, B.; Liermann, C.R.; Revenga, C.; Vorosmarty, C.; Fekete, B.; Crouzet, P.; Doll, P.; Endejan, M.; Frenken, K.; Magome, J.; et al. High-resolution mapping of the world's reservoirs and dams for sustainable river-flow management. Front. Ecol. Environ. 2011, 9, 494-502. [CrossRef]

20. Lehner, B.; Liermann, C.R.; Revenga, C.; Vörösmarty, C.; Fekete, B.; Crouzet, P.; Döll, P.; Endejan, M.; Frenken, K.; Magome, J. Global reservoir and dam (grand) database. Tech. Doc. Version 2011, 1, 1-14.

21. Reynaud, A.; Lanzanova, D. A global meta-analysis of the value of ecosystem services provided by lakes. Ecol. Econ. 2017, 137, 184-194. [CrossRef] [PubMed]

22. Landuyt, D.; Lemmens, P.; D’hondt, R.; Broekx, S.; Liekens, I.; De Bie, T.; Declerck, S.A.J.; De Meester, L.; Goethals, P.L.M. An ecosystem service approach to support integrated pond management: A case study using bayesian belief networks-highlighting opportunities and risks. J. Environ. Manag. 2014, 145, $79-87$. [CrossRef] [PubMed]

23. Nguyen, T.H.T.; Everaert, G.; Boets, P.; Forio, M.A.E.; Bennetsen, E.; Volk, M.; Hoang, T.H.T.; Goethals, P.L.M. Modelling tools to analyze and assess the ecological impact of hydropower dams. Water 2018, 10, 259. [CrossRef]

24. Boavida, I.; Santos, J.M.; Ferreira, T.; Pinheiro, A. Barbel habitat alterations due to hydropeaking. J. Hydro Environ. Res. 2015, 9, 237-247. [CrossRef]

25. Kennedy, T.A.; Muehlbauer, J.D.; Yackulic, C.B.; Lytle, D.A.; Miller, S.W.; Dibble, K.L.; Kortenhoeven, E.W.; Metcalfe, A.N.; Baxter, C.V. Flow management for hydropower extirpates aquatic insects, undermining river food webs. Bioscience 2016, 66, 561-575. [CrossRef]

26. Riascos, L.; Geerts, A.N.; Ona, T.; Goethals, P.; Cevallos-Cevallos, J.; Vanden Berghe, W.; Volckaert, F.A.M.; Bonilla, J.; Muylaert, K.; Velarde, E.; et al. DNA-based monitoring of the alien invasive north american crayfish procambarus clarkii in andean lakes (ecuador). Limnologica 2018, 70, 20-25. [CrossRef] 
27. Mereta, S.T.; Yewhalaw, D.; Boets, P.; Ahmed, A.; Duchateau, L.; Speybroeck, N.; Vanwambeke, S.O.; Legesse, W.; De Meester, L.; Goethals, P.L.M. Physico-chemical and biological characterization of anopheline mosquito larval habitats (diptera: Culicidae): Implications for malaria control. Parasit. Vectors 2013, 6, 320. [CrossRef] [PubMed]

28. Bartram, A.; El-Bizri, N.; Gittens, D. Water quality monitoring: A practical guide to the design and implementation of freshwater quality studies and monitoring programmes. In Recto Verso: Redefining the Sketchbook; Routledge: Abingdon-on-Thames, UK, 2016; pp. 23-32.

29. WHO. Guidelines for the Safe Use of Wastewater, Excreta and Greywater; World Health Organization: Geneva, Switzerland, 2006; Volume 3.

30. Giripunje, M.D.; Fulke, A.B.; Meshram, P.U. Remediation techniques for heavy-metals contamination in lakes: A mini-review. Clean Soil Air Water 2015, 43, 1350-1354. [CrossRef]

31. Brookes, J.D.; Antenucci, J.; Hipsey, M.; Burch, M.D.; Ashbolt, N.J.; Ferguson, C. Fate and transport of pathogens in lakes and reservoirs. Environ. Int. 2004, 30, 741-759. [CrossRef] [PubMed]

32. Seyfried, P.L.; Tobin, R.S.; Brown, N.E.; Ness, P.F. A prospective-study of swimming-related illness. 2. Morbidity and the microbiological quality of water. Am. J. Public Health 1985, 75, 1071-1075. [CrossRef] [PubMed]

33. IHA. Hydropower Sustainability Guidelines; International Hydropower Association: London, UK, 2018.

34. Edenhofer, O.; Pichs-Madruga, R.; Sokona, Y.; Seyboth, K.; Kadner, S.; Zwickel, T.; Eickemeier, P.; Hansen, G.; Schlömer, S.; von Stechow, C. Renewable Energy Sources and Climate Change Mitigation: Special Report of the Intergovernmental Panel on Climate Change; Cambridge University Press: Cambridge, UK, 2011.

35. Avnimelech, Y.; Verdegem, M.; Kurup, M.; Keshavanath, P. Sustainable land-based aquaculture: Rational utilization of water, land and feed resources. Mediterr. Aquac. J. 2008, 1, 45-55. [CrossRef]

36. Thu, P.M.; Populus, J. Status and changes of mangrove forest in mekong delta: Case study in tra vinh, vietnam. Estuar. Coast. Shelf. Sci. 2007, 71, 98-109. [CrossRef]

37. Fader, M.; Rost, S.; Muller, C.; Bondeau, A.; Gerten, D. Virtual water content of temperate cereals and maize: Present and potential future patterns. J. Hydrol. 2010, 384, 218-231. [CrossRef]

38. Biemans, H.; Haddeland, I.; Kabat, P.; Ludwig, F.; Hutjes, R.W.A.; Heinke, J.; von Bloh, W.; Gerten, D. Impact of reservoirs on river discharge and irrigation water supply during the 20th century. Water Resour. Res. 2011, 47. [CrossRef]

39. Ho, L.T.; Van Echelpoel, W.; Goethals, P.L.M. Design of waste stabilization pond systems: A review. Water Res. 2017, 123, 236-248. [CrossRef]

40. Ho, L.T.; Alvarado, A.; Larriva, J.; Pompeu, C.; Goethals, P. An integrated mechanistic modeling of a facultative pond: Parameter estimation and uncertainty analysis. Water Res. 2019, 151, 170-182. [CrossRef] [PubMed]

41. Mustajoki, J.; Hamalainen, R.P.; Marttunen, M. Participatory multicriteria decision analysis with web-hipre: A case of lake regulation policy. Environ. Modell. Softw. 2004, 19, 537-547. [CrossRef]

42. Sondergaard, M.; Jeppesen, E.; Lauridsen, T.L.; Skov, C.; Van Nes, E.H.; Roijackers, R.; Lammens, E.; Portielje, R. Lake restoration: Successes, failures and long-term effects. J. Appl. Ecol. 2007, 44, 1095-1105. [CrossRef]

43. Bednarek, A.T. Undamming rivers: A review of the ecological impacts of dam removal. Environ. Manag. 2001, 27, 803-814. [CrossRef]

44. Jeppesen, E.; Søndergaard, M.; Lauridsen, T.L.; Davidson, T.A.; Liu, Z.; Mazzeo, N.; Trochine, C.; Özkan, K.; Jensen, H.S.; Trolle, D.; et al. Chapter 6-Biomanipulation as a restoration tool to combat eutrophication: Recent advances and future challenges. In Advances in Ecological Research; Woodward, G., Jacob, U., O'Gorman, E.J., Eds.; Academic Press: Cambridge, MA, USA, 2012; Volume 47, pp. 411-488.

45. Tallar, R.Y.; Suen, J.P. Measuring the aesthetic value of multifunctional lakes using an enhanced visual quality method. Water 2017, 9, 322. [CrossRef]

46. Adrian, R.; O’Reilly, C.M.; Zagarese, H.; Baines, S.B.; Hessen, D.O.; Keller, W.; Livingstone, D.M.; Sommaruga, R.; Straile, D.; Van Donk, E.; et al. Lakes as sentinels of climate change. Limnol. Oceanogr. 2009, 54, 2283-2297. [CrossRef] [PubMed]

47. Mannina, G.; Cosenza, A.; Viviani, G. Micropollutants throughout an integrated urban drainage model: Sensitivity and uncertainty analysis. J. Hydrol. 2017, 554, 397-405. [CrossRef] 
48. Deblonde, T.; Cossu-Leguille, C.; Hartemann, P. Emerging pollutants in wastewater: A review of the literature. Int. J. Hyg. Environ. Health 2011, 214, 442-448. [CrossRef]

49. Bolong, N.; Ismail, A.F.; Salim, M.R.; Matsuura, T. A review of the effects of emerging contaminants in wastewater and options for their removal. Desalination 2009, 239, 229-246. [CrossRef]

50. Okeke, I.N.; Laxminarayan, R.; Bhutta, Z.A.; Duse, A.G.; Jenkins, P.; O’Brien, T.F.; Pablos-Mendez, A.; Klugman, K.P. Antimicrobial resistance in developing countries. Part I: Recent trends and current status. Lancet Infect. Dis. 2005, 5, 481-493. [CrossRef]

51. Okeke, I.N.; Klugman, K.P.; Bhutta, Z.A.; Duse, A.G.; Jenkins, P.; O’Brien, T.F.; Pablos-Mendez, A.; Laxminarayan, R. Antimicrobial resistance in developing countries. Part II: Strategies for containment. Lancet Infect. Dis. 2005, 5, 568-580. [CrossRef]

52. Xu, L.K.; Ouyang, W.Y.; Qian, Y.Y.; Su, C.; Su, J.Q.; Chen, H. High-throughput profiling of antibiotic resistance genes in drinking water treatment plants and distribution systems. Environ. Pollut. 2016, 213, 119-126. [CrossRef] [PubMed]

53. Florke, M.; Barlund, I.; van Vliet, M.T.H.; Bouwman, A.F.; Wada, Y. Analysing trade-offs between sdgs related to water quality using salinity as a marker. Curr. Opin. Environ. Sustain. 2019, 36, 96-104. [CrossRef]

54. Zhao, L.; Deng, J.H.; Sun, P.Z.; Liu, J.S.; Ji, Y.; Nakada, N.; Qiao, Z.; Tanaka, H.; Yang, Y.K. Nanomaterials for treating emerging contaminants in water by adsorption and photocatalysis: Systematic review and bibliometric analysis. Sci. Total Environ. 2018, 627, 1253-1263. [CrossRef] [PubMed]

55. Qian, F.; He, M.C.; Song, Y.H.; Tysklind, M.; Wu, J.Y. A bibliometric analysis of global research progress on pharmaceutical wastewater treatment during 1994-2013. Environ. Earth Sci. 2015, 73, 4995-5005. [CrossRef]

56. Wang, B.; Pan, S.Y.; Ke, R.Y.; Wang, K.; Wei, Y.M. An overview of climate change vulnerability: A bibliometric analysis based on web of science database. Nat. Hazards 2014, 74, 1649-1666. [CrossRef]

57. Vincon-Leite, B.; Casenave, C. Modelling eutrophication in lake ecosystems: A review. Sci. Total Environ. 2019, 651, 2985-3001. [CrossRef] [PubMed]

58. Tchounwou, P.B.; Yedjou, C.G.; Patlolla, A.K.; Sutton, D.J. Heavy metal toxicity and the environment. Exp. Suppl. 2012, 101, 133-164.

59. Yao, X.L.; Zhang, Y.L.; Zhang, L.; Zhou, Y.Q. A bibliometric review of nitrogen research in eutrophic lakes and reservoirs. J. Environ. Sci. 2018, 66, 274-285. [CrossRef]

60. Yang, W.; Zhou, H.J.; Si, F.Q.; Liu, C.; Wang, W.; Sun, Y.W.; Liu, W.Q.; Shan, C.G. Bibliometric analysis of greenhouse gas research on a global scale from 2000 to 2014. Curr. Sci. India 2018, 114, 1624-1631. [CrossRef]

61. Liu, X.J.; Zhang, L.A.; Hong, S. Global biodiversity research during 1900-2009: A bibliometric analysis. Biodivers. Conserv. 2011, 20, 807-826. [CrossRef]

62. Sweileh, W.M.; Zyoud, S.H.; Al-Jabi, S.W.; Sawalha, A.F.; Shraim, N.Y. Drinking and recreational water-related diseases: A bibliometric analysis (1980-2015). Ann. Occup. Environ. Med. 2016, 28, 40. [CrossRef] [PubMed]

63. Brandt, C.; Makarewicz, O.; Fischer, T.; Stein, C.; Pfeifer, Y.; Werner, G.; Pletz, M.W. The bigger picture: The history of antibiotics and antimicrobial resistance displayed by scientometric data. Int. J. Antimicrob. Agents 2014, 44, 424-430. [CrossRef] [PubMed]

64. Nikolic, N.; Bagliniere, J.L.; Rigaud, C.; Gardes, C.; Masquilier, M.L.; Taverny, C. Bibliometric analysis of diadromous fish research from 1970s to 2010: A case study of seven species. Scientometrics 2011, 88, 929-947. [CrossRef]

65. Jaric, I.; Cvijanovic, G.; Knezevic-Jaric, J.; Lenhardt, M. Trends in fisheries science from 2000 to 2009 : A bibliometric study. Rev. Fish. Sci. 2012, 20,70-79. [CrossRef]

66. Hassan, S.U.; Haddawy, P.; Zhu, J. A bibliometric study of the world's research activity in sustainable development and its sub-areas using scientific literature. Scientometrics 2014, 99, 549-579. [CrossRef]

67. Jiang, H.C.; Qiang, M.S.; Lin, P. A topic modeling based bibliometric exploration of hydropower research. Renew. Sustain. Energy Rev. 2016, 57, 226-237. [CrossRef]

68. Ding, L.Y.; Chen, L.Q.; Ding, C.Z.; Tao, J. Global trends in dam removal and related research: A systematic review based on associated datasets and bibliometric analysis. Chin. Geogr. Sci. 2019, 29, 1-12. [CrossRef]

69. Emmer, A. Glofs in the wos: Bibliometrics, geographies and global trends of research on glacial lake outburst floods (web of science, 1979-2016). Nat. Hazard Earth Syst. 2018, 18, 813-827. [CrossRef]

70. UN General Assembly. The 2030 Agenda for Sustainable Development; Resolution: Middlesbrough, UK, 2015.

71. OECD. Measuring Distance to the SDG Targets 2017; The Organisation for Economic Co-operation and Development: Paris, France, 2018. 
72. Griggs, D.; Nilsson, M.; Stevance, A.; McCollum, D. A Guide to SDG Interactions: From Science to Implementation; International Council for Science: Paris, France, 2017.

73. Pradhan, P.; Costa, L.; Rybski, D.; Lucht, W.; Kropp, J.P. A systematic study of sustainable development goal (sdg) interactions. Earths Future 2017, 5, 1169-1179. [CrossRef]

74. UN Water. Water and Sanitation Interlinkages across the 2030 Agenda for Sustainable Development; UN Water: Geneva, Switzerland, 2016.

75. Branche, E. The multipurpose water uses of hydropower reservoir: The share concept. Comptes Phys. 2017, 18, 469-478. [CrossRef]

76. Mugagga, F.; Nabaasa, B.B. The centrality of water resources to the realization of sustainable development goals (sdg). A review of potentials and constraints on the african continent. Int. Soil Water Conserv. 2016, 4, 215-223. [CrossRef]

77. The United Nations. The United Nations World Water Development Report 2016: Water and Jobs; United Nations Educational, Scientific and Cultural Organization: Paris, France, 2016.

78. Lin, C.Y.C.; Liscow, Z.D. Endogeneity in the environmental kuznets curve: An instrumental variables approach. Am. J. Agric. Econ. 2013, 95, 268-274. [CrossRef]

79. WCD. Dams and Development: A New Framework for Decision-Making: The Report of the World Commission on Dams; Earthscan: London, UK, 2000.

80. Riseng, C.M.; Wiley, M.J.; Black, R.W.; Munn, M.D. Impacts of agricultural land use on biological integrity: A causal analysis. Ecol. Appl. 2011, 21, 3128-3146. [CrossRef]

81. Sinclair, R.G.; Jones, E.L.; Gerba, C.P. Viruses in recreational water-borne disease outbreaks: A review. J. Appl. Microbiol. 2009, 107, 1769-1780. [CrossRef] [PubMed]

82. Craun, G.F.; Calderon, R.L.; Craun, M.F. Outbreaks associated with recreational water in the united states. Int. J. Environ. Health Res. 2005, 15, 243-262. [CrossRef] [PubMed]

83. Dickens, C.; Rebelo, L.-M.; Nhamo, L. Guidelines and Indicators for Target 6.6 of the SDGs: "Change in the Extent of Water-Related Ecosystems Over Time"; International Water Management Institute: Colombo, Sri Lanka, 2017.

84. Mekong River Commission. Mekong Climate Change Adaptation Strategy and Action Plan; Mekong River Commission: Vientiane, Laos, 2018.

85. Ansar, A.; Flyvbjerg, B.; Budzier, A.; Lunn, D. Should we build more large dams? The actual costs of hydropower megaproject development. Energy Policy 2014, 69, 43-56. [CrossRef]

86. Arcadis. Hydropower Generation in the Context of the EU WFD; European Commission: Brussels, Belgium, 2011.

87. Giguet-Covex, C.; Arnaud, F.; Poulenard, J.; Enters, D.; Reyss, J.L.; Millet, L.; Lazzaroto, J.; Vidal, O. Sedimentological and geochemical records of past trophic state and hypolimnetic anoxia in large, hard-water lake bourget, french alps. J. Paleolimnol. 2010, 43, 171-190. [CrossRef]

88. Jenny, J.P.; Arnaud, F.; Dorioz, J.M.; Covex, C.G.; Frossard, V.; Sabatier, P.; Millet, L.; Reyss, J.L.; Tachikawa, K.; Bard, E.; et al. A spatiotemporal investigation of varved sediments highlights the dynamics of hypolimnetic hypoxia in a large hard-water lake over the last 150 years. Limnol. Oceanogr. 2013, 58, 1395-1408. [CrossRef]

89. Berga, L. The role of hydropower in climate change mitigation and adaptation: A review. Engineering 2016, 2, 313-318. [CrossRef]

90. Boehlert, B.; Strzepek, K.M.; Gebretsadik, Y.; Swanson, R.; McCluskey, A.; Neumann, J.E.; McFarland, J.; Martinich, J. Climate change impacts and greenhouse gas mitigation effects on us hydropower generation. Appl. Energy 2016, 183, 1511-1519. [CrossRef]

91. Tranvik, L.J.; Downing, J.A.; Cotner, J.B.; Loiselle, S.A.; Striegl, R.G.; Ballatore, T.J.; Dillon, P.; Finlay, K.; Fortino, K.; Knoll, L.B.; et al. Lakes and reservoirs as regulators of carbon cycling and climate. Limnol. Oceanogr. 2009, 54, 2298-2314. [CrossRef]

92. Williamson, C.E.; Saros, J.E.; Vincent, W.F.; Smol, J.P. Lakes and reservoirs as sentinels, integrators, and regulators of climate change. Limnol. Oceanogr. 2009, 54, 2273-2282. [CrossRef]

93. Hamududu, B.; Killingtveit, A. Assessing climate change impacts on global hydropower. Energies 2012, 5, 305-322. [CrossRef]

94. Pittock, J. Better management of hydropower in an era of climate change. Water Altern. 2010, 3, 444-452.

95. Gaudard, L.; Gilli, M.; Romerio, F. Climate change impacts on hydropower management. Water Resour. Manag. 2013, 27, 5143-5156. [CrossRef]

96. Kim, U.; Kaluarachchi, J.J. Climate change impacts on water resources in the upper blue nile river basin, ethiopia. J. Am. Water Resour. Assoc. 2009, 45, 1361-1378. [CrossRef] 
97. Lauri, H.; de Moel, H.; Ward, P.J.; Rasanen, T.A.; Keskinen, M.; Kummu, M. Future changes in mekong river hydrology: Impact of climate change and reservoir operation on discharge. Hydrol. Earth Syst. Sci. 2012, 16, 4603-4619. [CrossRef]

98. Paerl, H.W.; Huisman, J. Climate-blooms like it hot. Science 2008, 320, 57-58. [CrossRef]

99. Jeppesen, E.; Meerhoff, M.; Davidson, T.A.; Trolle, D.; Sondergaard, M.; Lauridsen, T.L.; Beklioglu, M.; Brucet, S.; Volta, P.; Gonzalez-Bergonzoni, I.; et al. Climate change impacts on lakes: An integrated ecological perspective based on a multi-faceted approach, with special focus on shallow lakes. J. Limnol. 2014, 73, 88-111. [CrossRef]

100. Havens, K.; Jeppesen, E. Ecological responses of lakes to climate change. Water 2018, 10, 917. [CrossRef]

101. Vorosmarty, C.J.; Fekete, B.M.; Meybeck, M.; Lammers, R.B. Global system of rivers: Its role in organizing continental land mass and defining land-to-ocean linkages. Glob. Biogeochem. Cycles 2000, 14, 599-621. [CrossRef]

102. Chapin, F.S.; Chapin, M.C.; Matson, P.A.; Vitousek, P. Principles of Terrestrial Ecosystem Ecology; Springer: New York, NY, USA, 2011.

103. Schimel, D.S. Terrestrial ecosystems and the carbon cycle. Glob. Chang. Biol. 1995, 1, 77-91. [CrossRef]

104. Ballinger, A.; Lake, P.S. Energy and nutrient fluxes from rivers and streams into terrestrial food webs. Mar. Freshw. Res. 2006, 57, 15-28. [CrossRef]

105. Gratton, C.; Donaldson, J.; vander Zanden, M.J. Ecosystem linkages between lakes and the surrounding terrestrial landscape in northeast iceland. Ecosystems 2008, 11, 764-774. [CrossRef]

106. Brönmark, C.; Hansson, L.A. The Biology of Lakes and Ponds; OUP Oxford: Oxford, UK, 2005.

107. Pejchar, L.; Mooney, H.A. Invasive species, ecosystem services and human well-being. Trends Ecol. Evol. 2009, 24, 497-504. [CrossRef]

108. Keesstra, S.D.; Bouma, J.; Wallinga, J.; Tittonell, P.; Smith, P.; Cerda, A.; Montanarella, L.; Quinton, J.N.; Pachepsky, Y.; van der Putten, W.H.; et al. The significance of soils and soil science towards realization of the united nations sustainable development goals. Soil 2016, 2, 111-128. [CrossRef]

109. Szabo, S.; Nicholls, R.J.; Neumann, B.; Renaud, F.G.; Matthews, Z.; Sebesvari, Z.; AghaKouchak, A.; Bales, R.; Ruktanonchai, C.W.; Kloos, J.; et al. Making sdgs work for climate change hotspots. Environment 2016, 58, 24-33. [CrossRef]

110. Ntona, M.; Morgera, E. Connecting sdg 14 with the other sustainable development goals through marine spatial planning. Mar. Policy 2018, 93, 214-222. [CrossRef]

111. Brundtland Commission. Report of the World Commission on Environment and Development: Our Common Future; Oxford University Press: Oxford, UK, 1987. 